\title{
Anti-Müllerian Hormone and Sertoli Cell Function in Paediatric Male Hypogonadism
}

\author{
Romina P. Grinspon ${ }^{a}$ Rodolfo A. Rey ${ }^{a, b}$ \\ ${ }^{a}$ Centro de Investigaciones Endocrinológicas (CEDIE, CONICET), Hospital de Niños Ricardo Gutiérrez, \\ ${ }^{b}$ Department of Histology, Cell Biology, Embryology and Genetics, School of Medicine, University of Buenos Aires, \\ Buenos Aires, Argentina
}

\section{Key Words}

Hypogonadotrophic hypogonadism • Hypergonadotrophic hypogonadism $\cdot$ Testis $\cdot$ Anorchia $\cdot$ Cryptorchidism $\cdot$ Sex development disorders

\begin{abstract}
In the prepubertal male, Sertoli cells are the most active testicular cell population. Without stimulation tests, prepubertal hypogonadism can only be evidenced if Sertoli cell function is assessed. Anti-müllerian hormone (AMH) is a distinctive marker of the prepubertal Sertoli cell. Serum AMH is high from fetal life until puberty. In postnatal life, AMH testicular production is stimulated by FSH and potently inhibited by androgens. In anorchid patients, AMH is undetectable. In prepubertal males with fetal- or childhood-onset primary or central hypogonadism affecting the whole gonad, serum AMH is low. Conversely, when hypogonadism only affects Leydig cells (i.e., LH/human chorionic gonadotrophin receptor or steroidogenic enzyme defects), serum $\mathrm{AMH}$ is normal/high. AMH is also normal/high in patients with androgen insensitivity. In patients of pubertal age with central hypogonadism, AMH is low for Tanner stage - reflecting lack of FSH stimulus, - but high for age - reflecting lack of testosterone inhibitory effect. FSH treatment results
\end{abstract}

in serum AMH rise, whereas human chorionic gonadotrophin treatment increases testosterone levels which inhibit AMH production. In conclusion, AMH determination is helpful in assessing gonadal function, without need for stimulation tests, and orientates the aetiological diagnosis of paediatric male hypogonadism. Furthermore, serum AMH is an excellent marker of FSH and androgen action in the testis.

Copyright $\odot 2010$ S. Karger AG, Basel

The testes are composed by two different compartments: the seminiferous tubules, containing germ and Sertoli cells, and the interstitial tissue, containing Leydig cells. Testicular function is mainly regulated by pituitary gonadotrophins $\mathrm{LH}$ and FSH, whose secretion is induced by the hypothalamic gonadotrophin-releasing hormone $(\mathrm{GnRH})$. The hypothalamic-pituitary-testicular axis shows specific maturational changes in each of its components from fetal life through adulthood. The biological aspects of Sertoli cell function have been recently reviewed [1]. Here, we will address the relevance of Sertoli cell physiology and pathophysiology in the understanding of prepubertal male hypogonadism.

\section{KARGER \\ Fax +4161306 1234 \\ E-Mail karger@karger.ch}

www.karger.com (c) 2010 S. Karger AG, Basel

1663-2818/10/0732-0081\$26.00/0

Accessible online at:

www.karger.com/hrp
Rodolfo Rey, MD, PhD

Centro de Investigaciones Endocrinológicas

Hospital de Niños Ricardo Gutiérrez

Gallo 1330, C1425EFD Buenos Aires (Argentina)

Tel. +54 114963 5931, Fax +54 114963 5930, E-Mail rodolforey@ cedie.org.ar 


\section{Normal Development of the}

Hypothalamic-Pituitary-Testicular Axis

\section{Fetal Life}

Testis differentiation, by the end of the 5th embryonic week, is characterised by the aggregation of Sertoli and germ cells to form the seminiferous cords. Sertoli cells synthesise anti-müllerian hormone $(\mathrm{AMH})$, responsible for the regression of müllerian ducts, the anlagen of the uterus and fallopian tubes. The initiation of AMH secretion is independent of pituitary function. Afterwards, fetal FSH regulates Sertoli cell activity [1]. Leydig cells differentiate a few days later and secrete testosterone [2] and INSL3 [3], stimulated by placental human chorionic gonadotrophin (hCG). Androgens are responsible, during the first trimester, for the differentiation of the wolffian duct into the epididymis, seminal vesicle, and vas deferens, as well as for the masculinisation of the external genitalia. During the third trimester, LH is the main stimulus for testosterone secretion, responsible for the second phase of testicular descent and for penile growth. INSL3, also regulated by hCG and $\mathrm{LH}$, is the main responsible for the first phase of testicular descent during the second trimester [3].

\section{Neonatal Period, Infancy and Childhood}

During the whole prepubertal period - between birth and the onset of puberty - very few changes are observed in the hypothalamic-pituitary-gonadal axis. The seminiferous tubules show no lumen and immature Sertoli cells. Germ cells are represented solely by gonocytes and spermatogonia, which proliferate by mitosis. Typical Leydig cells persist for 3-6 months and then disappear from the interstitial tissue of the testis until puberty. The appearance of external genitalia does not show major changes.

Gonadotrophin secretion, transiently low in the first week of life [4], increases in the second week and remains high during the first 3-6 months of life [5]. LH stimulates Leydig cell testosterone production, while FSH stimulates Sertoli cell proliferation and AMH and inhibin B secretion. Thereafter, gonadotrophins decrease again resulting in a fall of testicular testosterone secretion to very low or undetectable levels during infancy and childhood (fig. 1a). Childhood is therefore a period of physiologic hypogonadotrophic hypoandrogenism. Testicular volume, assessed clinically by palpation and comparison with Prader's orchidometer - a method with low sensitivity to detect small changes in gonadal size, - also shows no major changes (1-2
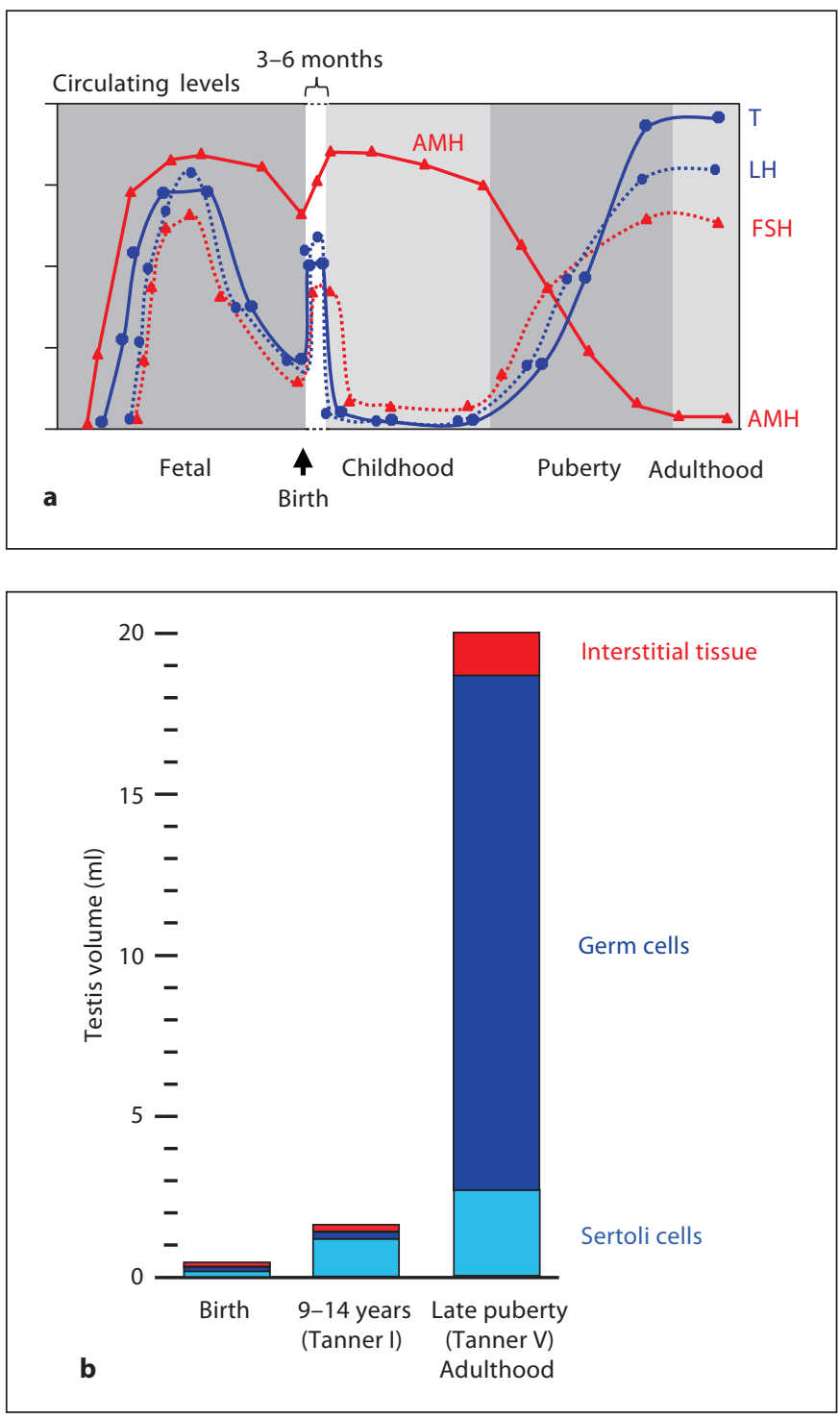

Fig. 1. a Schematic ontogeny of circulating levels of gonadotrophins, testosterone (T) and AMH in the male. b Schematic ontogeny of the evolution of testicular volume from birth to adulthood. Seminiferous tubules (Sertoli + germ cells) are always the major component of the testis. From birth and during the whole prepubertal period (i.e., until ages 9-14 years, Tanner stage I), seminiferous tubule volume depends mainly on Sertoli cells, whereas the significant increase in testicular volume during pubertal development (i.e., between Tanner stages I and V) is mainly due to germ cell proliferation.

$\mathrm{ml})$. For these reasons, the prepubertal testis has been classically described as quiescent. However, when attention is driven to Sertoli cells, it becomes clear that there is an intense activity. The use of accurate methods of evaluation has shown that testis size increases from ap- 
Fig. 2. Relationship between serum testosterone, androgen receptor (AR) expression in Sertoli cells and serum AMH from birth to puberty. AR expression in Sertoli cells is represented as the percentage of Sertoli cells with AR immunolabelling [data from $28,45]$.

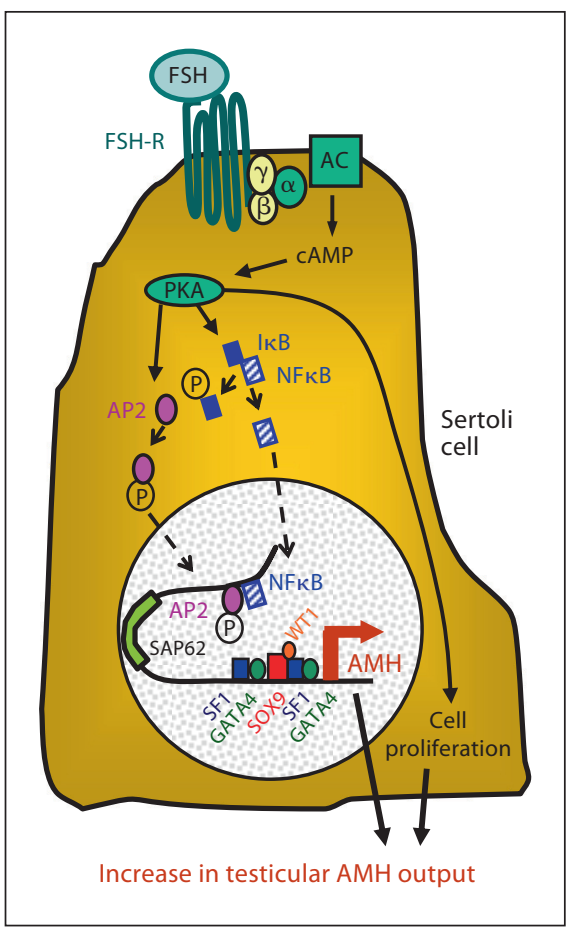

Fig. 3. FSH regulation of testicular AMH secretion. FSH binds to the FSH receptor (FSH-R) present on Sertoli cell membrane, and triggers protein G-mediated activation of adenylyl cyclase (AC), resulting in an increase of cyclic AMP (cAMP) levels and activation of protein kinase A (PKA). PKA induces Sertoli cell proliferation and also nuclear translocation of transcription factors $\mathrm{AP} 2$ and NFKB, which bind to specific response elements on the distal $\mathrm{AMH}$ promoter, enhancing $\mathrm{AMH}$ expression [data from 22].

proximately $0.5 \mathrm{~cm}^{3}$ in the first year of life to $1.5 \mathrm{~cm}^{3}$ at 10 years [6], mainly due to Sertoli cell proliferation [7] (fig. 1b). AMH, a conspicuous marker of Sertoli cell function, remains high during the whole prepubertal period.

$\mathrm{AMH}$ and Sertoli Cell Function in

Paediatric Male Hypogonadism

\section{Puberty}

The reactivation of the hypothalamic-gonadotrophin axis induces Leydig cells functional activity again. Intratesticular androgen concentration increases before serum testosterone does [8], and provokes Sertoli cell maturation. Sertoli cells stop proliferating, AMH production is down-regulated [9] (fig. 2) and inhibin B secretion increases [10]. Pubertal spermatogenesis is triggered: spermatogonia differentiate into primary spermatocytes, which undergo meiosis and form spermatids that subsequently mature to spermatozoa.

Clinically, the onset of puberty is defined by a testicular volume $\geq 4 \mathrm{ml}$. The subsequent increase of gonadal size to a final volume of $15-25 \mathrm{ml}$ is dependent on germ cell proliferation (fig. 1b), which depends on intratesticular androgen levels and normal androgen receptor function in Sertoli cells.

\section{AMH and Sertoli Cell Physiology}

\section{AMH Ontogeny}

$\mathrm{AMH}$ is a distinctive marker of the immature Sertoli cell. Except for a transient decline in the perinatal period, AMH levels remain high from the end of the 7 th fetal week until the onset of puberty (table 1$)[4,11,12]$. No extragonadal AMH source has been found. AMH is also produced by the ovaries $[12,13]$, at very low levels (table 1 ).

\section{AMH Regulation}

\section{Up-Regulation of AMH}

Onset of AMH Expression in Fetal Life Is Gonadotrophin Independent. Binding of SOX9 to the AMH promoter is essential for the initiation of $\mathrm{AMH}$ expression in 
Table 1. Serum AMH in normal males and females, using the AMH/MIS ELISA from Beckman-Coulter-Immunotech [data from 13, 45]

\begin{tabular}{|c|c|c|c|c|}
\hline \multirow[t]{3}{*}{ Age group } & \multicolumn{4}{|c|}{ Serum AMH } \\
\hline & \multicolumn{2}{|l|}{$\mathrm{pmol} / 1$} & \multicolumn{2}{|l|}{$\mu g / 1$} \\
\hline & males & females & males & females \\
\hline 2 days & $371 \pm 168$ & $7.4 \pm 6.3$ & $52.0 \pm 23.5$ & $1.0 \pm 0.9$ \\
\hline 7 days & $397 \pm 152$ & & $55.6 \pm 21.3$ & \\
\hline 10 days & $427 \pm 127$ & & $59.8 \pm 17.8$ & \\
\hline 20 days & $523 \pm 156$ & & $73.2 \pm 21.8$ & \\
\hline 1 month -0.9 years & $793 \pm 264$ & $18.2 \pm 21.3$ & $97.9 \pm 34.3$ & $2.5 \pm 3.0$ \\
\hline $1-4.9$ years & $699 \pm 245$ & & $111.1 \pm 37.0$ & \\
\hline \multicolumn{5}{|l|}{ 5-12 years: } \\
\hline Tanner I & $516 \pm 275$ & $22.8 \pm 19.6$ & $72.3 \pm 38.5$ & $3.2 \pm 2.7$ \\
\hline \multicolumn{5}{|l|}{ >10 years: } \\
\hline Tanner II & $249 \pm 126$ & & $34.9 \pm 17.6$ & \\
\hline III & $98 \pm 65$ & & $13.7 \pm 9.1$ & \\
\hline IV-V/adults & $42 \pm 38$ & $13.7 \pm 18.8$ & $5.9 \pm 5.3$ & $1.9 \pm 2.6$ \\
\hline
\end{tabular}

early fetal development [14, 15], independently from FSH action. SF1 [14, 16, 17], GATA4 [17, 18] and WT1 [19] further enhance AMH transcription.

FSH Increases Basal AMH Testicular Production. Although basal AMH expression is FSH independent, serum $\mathrm{AMH}$ is low in patients with congenital hypogonadotrophic hypogonadism, and increases in response to exogenous FSH administration [20, 21], indicating that serum AMH is a useful marker of FSH action on the prepubertal testis. Experimental models have shown that lack of FSH stimulation during fetal and neonatal life results in low AMH owing to a decrease in both Sertoli cell number and AMH expression. Low serum AMH correlated with small testes [22]. Both in mice [23] and humans [20], FSH administration results in an increased testis volume and in $\mathrm{AMH}$ transcriptional activity through the classical FSH receptor transduction pathway involving Gs $\alpha$ protein, adenylyl cyclase and protein kinase A (fig. 3), with subsequent nuclear translocation of transcription factors NFKB and AP2, which bind to specific response elements in the AMH promoter [22].

\section{Inhibition of $A M H$}

Androgens Are Potent Inhibitors of AMH Production in Sertoli Cells. AMH decreases during puberty, mainly between Tanner stages II and III [24], in coincidence with the increase of intratesticular testosterone concentration. This negative correlation between testosterone and $\mathrm{AMH}$ is observed also in central precocious puberty and in gonadotrophin-independent precocious puberty (testotoxicosis), suggesting that androgens are responsible for $\mathrm{AMH}$ down-regulation independently of age and of gonadotrophin levels [24]. Furthermore, in patients with constitutional delay of puberty [25] or with defective androgen production or sensitivity [26, 27], AMH levels remain at high prepubertal levels. The inhibitory effect of androgens prevails over the positive effect of FSH on AMH secretion in the pubertal testis (fig. 4).

The surprising coexistence of high levels of androgens and $\mathrm{AMH}$ during fetal life and the first months after birth is explained by the physiological androgen insensitivity of Sertoli cells in these periods, owing to the lack of androgen receptor expression in Sertoli cell nuclei (fig. 2, 4) $[23,28-30]$.

Meiosis Is Also Associated with AMH Down-Regulation. During human puberty, AMH expression is significantly down-regulated in the seminiferous tubules after meiotic onset [31]. Experimental observations in $\mathrm{XXsxr}^{\mathrm{b}}$ male mice, a model for the human XX male, indicate that meiotic germ cells may play a role in the inhibition of AMH expression [23].

\section{Hypogonadism: Definitions and Classification}

\section{Definition of Hypogonadism}

Usually, the term hypogonadism is applied in the adult male to describe testicular failure associated with androgen deficiency and/or disorders in sperm production. This classical definition does not take into account the potential deficiencies in the various testicular cell popu- 


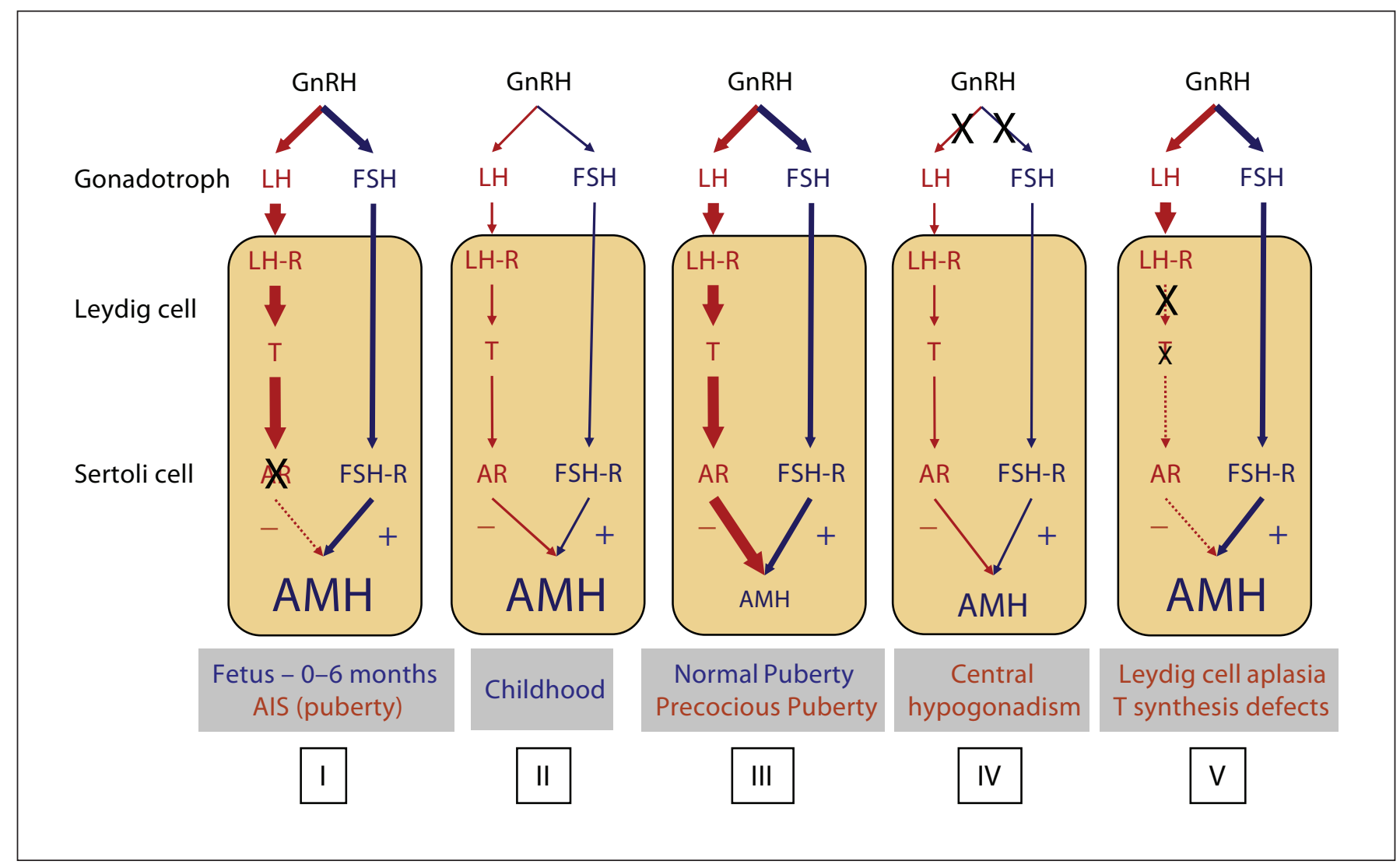

Fig.4. Regulation of testicular AMH secretion by gonadotrophins and androgens. In general, the hypothalamus regulates $\mathrm{LH}$ and FSH secretion by the gonadotroph through the GnRH. LH acts on the $\mathrm{LH}$ receptor (LH-R) present in Leydig cells, inducing testosterone (T) secretion. FSH acts on the FSH receptor (FSH-R) present in Sertoli cells. The hypothalamic-pituitary-gonadal axis is active in the fetus and early infancy, is quiescent during childhood, and is reactivated at puberty. FSH is a moderate inducer of $\mathrm{AMH}$ secretion, whereas T, acting through the androgen receptor (AR), is a potent inhibitor of AMH production. In the normal fetus and infant, as well as in patients with the AIS, the lack of AR expression results in high AMH production by Sertoli cells (I). During childhood, there is a physiologic hypogonadotrophic state

lations. In the prepubertal male, Sertoli cells are the most active testicular cell population, while testosterone and sperm production are physiologically inexistent. Therefore, male hypogonadism in the boy can only be discovered if Sertoli cell function is assessed. A more comprehensive clinical definition of hypogonadism includes decreased testicular function involving a disorder of gamete production or function, Leydig cell hormone production (androgens and INSL3) and/or Sertoli cell hormone production (AMH and inhibin B).

$\mathrm{AMH}$ and Sertoli Cell Function in

Paediatric Male Hypogonadism resulting in very low $\mathrm{T}$; $\mathrm{AMH}$ levels remain high, but somewhat lower probably due to the lack of FSH stimulus (II). In normal or precocious puberty, T prevails over $\mathrm{FSH}$, resulting in $\mathrm{AMH}$ inhibition (III). In congenital central hypogonadism, AMH is lower than in the normal boy because of the longstanding lack of FSH from fetal life; however, at pubertal age, the inhibitory effect of T is also absent, and AMH remains higher than in normal puberty (IV). In Leydig cell-specific primary hypogonadism (Leydig cell aplasia or hypoplasia due to LH-R defects, or in defects of steroidogenesis), the inhibitory effect of androgens is absent, and $\mathrm{AMH}$ levels are high. The orange area represents the testis. Thickness of lines is in correlation with hormone effect on its target.

\section{Classification of Hypogonadism (table 2)}

\section{Testicular (Primary), Hypothalamic-Pituitary \\ (Central) or Combined}

Male hypogonadism can be classified according to the level of the hypothalamic-pituitary-gonadal axis that is primarily affected. In central hypogonadism, gonadal failure results from a malfunction of the hypothalamic GnRH pulse generator or the pituitary gonadotroph to secrete LH and FSH. In primary hypogonad-

Horm Res Paediatr 2010;73:81-92 
Table 2. Classification of hypogonadism

Whole testicular dysfunction

Cell-specific testicular dysfunction

\begin{tabular}{|c|c|}
\hline $\begin{array}{l}\text { Central hypogonadism } \\
\text { Fetal-onset } \\
\quad \text { (1st trimester) }\end{array}$ & Inexistent \\
\hline $\begin{array}{l}\text { Fetal-onset } \\
\qquad(2 \text { nd-3rd trimesters) }\end{array}$ & $\begin{array}{l}\text { Isolated hypogonadotrophic hypogonadism } \\
\text { Gene mutations: GnRH-R, KAL1, FGFR1, GRP54, Le } \\
\text { Leptin-R } \\
\text { Multiple pituitary hormone deficiency } \\
\text { Gene mutations: HESX1, LHX3, PROP1, OTX2 } \\
\text { Other causes of septo-optic dysplasia and defects of } \mathrm{n}\end{array}$ \\
\hline Childhood-onset & $\begin{array}{l}\text { Isolated hypogonadotrophic hypogonadism } \\
\text { Endocrine disorders: hypothyroidism, hyperprolactir } \\
\text { Multiple pituitary hormone deficiency } \\
\text { Central nervous system tumours, Langerhans' hystio }\end{array}$ \\
\hline Peripubertal-onset & $\begin{array}{l}\text { Isolated hypogonadotrophic hypogonadism } \\
\text { Functional central hypogonadism: anorexia nervosa } \\
\text { Endocrine disorders: hypothyroidism, hyperprolactir } \\
\text { Multiple pituitary hormone deficiency } \\
\text { Central nervous system tumours, Langerhans' hystio }\end{array}$ \\
\hline $\begin{array}{l}\text { Primary hypogonadism } \\
\text { Fetal-onset } \\
\quad \text { (1st trimester) }\end{array}$ & $\begin{array}{l}\text { Gonadal dysgenesis } \\
\text { Gene mutations: SRY, SOX9, ATRX, WT1 } \\
\text { Chromosomal abnormalities: 9p deletion, DSS (Xq) } \\
\text { duplication, } 45, \mathrm{X} / 46, \mathrm{XY}\end{array}$ \\
\hline
\end{tabular}

Inexistent

Leydig cells

Isolated LH deficiency

(LH $\beta$-subunit gene mutation)

Sertoli cells

Isolated FSH deficiency

(FSH $\beta$-subunit gene mutation)

Inexistent

Endocrine disorders: hypothyroidism, hyperprolactinemia

ultiple pituitary hormone deficiency

Functional central hypogonadism: anorexia nervosa

Inexistent

actinemia

ltiple pituitary hormone deficiency

Central nervous system tumours, Langerhans' hystiocytosis

Primary hypogonadism

tal-onset
Leydig cell

Leydig cell aplasia/hypoplasia: LH/

hCG-R mutation

Steroidogenic protein defects: StAR, P450scc, P450c17, 3ß-HSD, 17 $\beta$-HSD

Sertoli cell

AIS: AR mutation

PMDS: AMH mutation

\begin{tabular}{|c|c|c|}
\hline $\begin{array}{l}\text { Fetal-onset } \\
\qquad(2 \text { nd-3rd trimesters })\end{array}$ & $\begin{array}{l}\text { Testicular dysgenesis syndrome } \\
\text { Endocrine disruptors } \\
\text { Testicular regression syndrome } \\
\text { Testicular torsion } \\
\text { Mild gonadal dysgenesis }\end{array}$ & $\begin{array}{l}\text { Sertoli cell } \\
\text { FSH-R mutation }\end{array}$ \\
\hline Childhood-onset & $\begin{array}{l}\text { Cryptorchidism } \\
\text { Testicular torsion } \\
\text { Orchitis } \\
\text { Chemotherapy/radiotherapy } \\
\text { Klinefelter syndrome (germ cell depletion) }\end{array}$ & Inexistent \\
\hline Peripubertal-onset & $\begin{array}{l}\text { Cryptorchidism } \\
\text { Testicular torsion } \\
\text { Orchitis } \\
\text { Chemotherapy/radiotherapy } \\
\text { Klinefelter syndrome (Sertoli and Leydig cell dysfunction) }\end{array}$ & $\begin{array}{l}\text { Germ cells } \\
\text { XX male }\end{array}$ \\
\hline $\begin{array}{l}\text { Fetal-onset } \\
\text { (2nd-3rd trimesters) }\end{array}$ & Prader-Willi syndrome & Inexistent \\
\hline Childhood-onset & Total body irradiation & Inexistent \\
\hline Peripubertal-onset & Total body irradiation & Inexistent \\
\hline
\end{tabular}


ism, a primary testicular failure exists. Certain disorders may impair both the hypothalamic-pituitary axis and the testis concomitantly, and provoke a combined hypogonadism.

\section{Whole or Cell-Specific Testicular Dysfunction}

Primary, central or combined hypogonadism may reflect the concomitant impairment of all testicular cell populations; in this case, there is a 'whole testicular dysfunction or hypogonadism'. Alternatively, only one of the testicular cell populations (germ, Sertoli or Leydig) may be primarily affected; in this case, there is a 'dissociated or cell-specific testicular failure or hypogonadism’.

Fetal-, Childhood-, Puberty-, Adulthood-, or

Late-Onset Hypogonadism

The clinical consequences of male hypogonadism depend on the period of life in which it is established. Fetalonset hypogonadism in the first trimester results in disorders of sex development (DSD) presenting with ambiguous or female genitalia, owing to the lack or to insufficient levels of testis hormone secretion during the critical window of male sex differentiation. It should be noted that in a patient carrying a Y chromosome, DSD due to hypogonadism are always primary gonadal dysfunctions: gonadal dysgenesis represents a whole gonadal dysfunction, whereas Leydig cell aplasia/hypoplasia and steroidogenic defects are cell-specific gonadal forms of hypogonadism. Central hypogonadism cannot result in genital ambiguity, since Leydig cell function in the first trimester of fetal life is dependent on hCG and not on fetal pituitary LH. If established during the second or third trimester, fetal hypogonadism - which may be primary, central or combined - results in micropenis and/ or cryptorchidism. When established during infancy or childhood, hypogonadism may remain undiagnosed until the age of puberty - unless Sertoli cell function is assessed. At pubertal age, hypogonadism can provoke lack or arrest of pubertal development. During adulthood and senescence, hypogonadism leads to infertility and/ or impaired androgen-regulated physiological functions (impaired sexual activity, body composition, bone mineral density, etc.).

\section{AMH Levels in Prepubertal Male Hypogonadism}

Because gonadotrophin and testosterone levels normally decrease to very low values until the onset of puberty, and only Sertoli cells remain active during child- hood, the evaluation of gonadal function in the prepubertal male relies mainly on the assessment of Sertoli cell products [32-35]. In the male, AMH is secreted exclusively by Sertoli cells; therefore, serum AMH reliably reflects the presence and function of testes in prepubertal boys, without the need for any stimulation tests $[33,36$, 37].

In this section, we shall address - based on an aetiological approach - how the different disorders causing hypogonadism affect AMH testicular production.

\section{Central Hypogonadism with 'Whole Testicular Dysfunction'}

\section{Isolated Gonadotrophin Deficiency}

Low serum AMH levels have been reported in infants with congenital central hypogonadism. Early postnatal treatment with recombinant human FSH (rhFSH) mimicked the physiological development occurring after birth, resulting in an increase of testicular size - presumably by FSH-induced Sertoli cell proliferation - and an elevation in serum AMH [20].

In untreated patients of pubertal age with congenital hypogonadotrophic hypogonadism, serum AMH is elevated for age - because serum testosterone remains at prepubertal levels and does not down-regulate AMH but lower than expected for patient's Tanner stage and serum testosterone $[21,38]$ - reflecting the lack of FSH stimulus (fig. 4; table 3). Treatment with rhFSH increases serum AMH; further treatment with hCG, resulting in androgen production locally by the testes, mimics the physiological inhibition of $\mathrm{AMH}$ observed at puberty (fig. 5). Conversely, inhibition of AMH is less significant when patients are supplemented with exogenous testosterone, which probably indicates that intratesticular testosterone reaches much lower levels [21].

\section{Multiple Pituitary Hormone Deficiency}

Although there are no published studies on AMH levels in patients with multiple pituitary hormone deficiency, serum AMH might be lower than in patients with isolated hypogonadotrophic hypogonadism. In fact, in experimental conditions GH regulates Sertoli cell function [39] and IGF-I and IGF-II regulate testicular interstitial cell steroidogenesis, proliferation and apoptosis [40]. 
Table 3. Expected levels of gonadotrophins, testosterone and $\mathrm{AMH}$ in normal male development and in disorders affecting AMH production

\begin{tabular}{|c|c|c|c|c|}
\hline & FSH & LH & $\mathrm{AMH}$ & Testosterone \\
\hline Normal fetus and postnatal 0-6 months & high & high & high & high \\
\hline Normal childhood & low & low & high & low \\
\hline Normal puberty & high & high & very low & high \\
\hline AIS (puberty) & high & high & high & high \\
\hline Central hypogonadism & very low & very low & low & very low \\
\hline Leydig cell aplasia/T-synthesis defects & high & high & high & very low \\
\hline Precocious puberty & high & high & very low & high \\
\hline
\end{tabular}

\section{Central Hypogonadism with 'Cell-Specific Testicular Dysfunction'}

\section{Central Hypogonadism with Sertoli Cell-Specific Dysfunction}

Although not yet reported, low serum AMH could be expected in patients with isolated FSH deficiency due to FSH $\beta$-subunit gene mutations [41]. Transgenic mice carrying a deletion of the FSH $\beta$-subunit gene have low serum AMH, in correlation with reduced Sertoli cell number and testicular volume. All parameters resumed normal values after FSH administration [22].

\section{Central Hypogonadism with Leydig Cell-Specific \\ Dysfunction}

Isolated LH deficiency, due to mutations of the LH $\beta$ subunit gene, results in failure of Leydig cell differentiation and testosterone secretion in late fetal life and pubertal age [42]. In mice, FSH levels are usually elevated and Sertoli cells remain immature, producing high AMH levels [43].

\section{Primary Hypogonadism with 'Whole Testicular Dysfunction'}

\section{Complete Gonadal Dysgenesis, Vanishing Testes and Anorchia}

When due to early-onset complete gonadal dysgenesis, the absence of testicular tissue results in a DSD with female external genitalia, whereas vanishing or regression of testicular tissue occurring later in fetal life is associated with male genitalia, micropenis and hypoplastic scrotum. In all cases, the absence of gonadal tissue results in undetectable serum AMH $[27,36,37]$.



Fig. 5. Effect of recombinant human FSH (rhFSH) and hCG treatment on testicular AMH production by the testis in patients with previously untreated central hypogonadism. Initial treatment with rhFSH during 30 days resulted in an elevation of serum AMH in all 8 patients, while testosterone (T) remained at prepubertal levels. The shaded area represents normal AMH for Tanner I stage, according to T levels observed in these patients. Subsequent addition of hCG treatment resulted in an elevation of $\mathrm{T}$ which provoked a decline in serum AMH. The shaded area represents AMH values for Tanner IV-V stages, according to T levels observed in the treated patients. ${ }^{*},{ }^{* *}$ and ${ }^{* * *}$ indicate $\mathrm{p}<0.05$, $\mathrm{p}<0.01$ and $\mathrm{p}<0.001$, respectively [data from 21].

\section{Partial Testicular Dysgenesis}

Early-onset partial testicular dysgenesis in XY patients usually results in DSD with ambiguous genitalia. Both tubular and interstitial compartments of the testes are affected producing insufficient AMH and testosterone [27, 44]. Serum AMH is low and usually correlates with the amount of functional Sertoli cells [31]. In most boys with 
isolated hypospadias, $\mathrm{AMH}$ and testosterone are normal, indicating that there is no testicular dysfunction [45].

Late-onset testicular dysgenesis is a typical feature of Klinefelter syndrome. No overt signs of hypogonadism are evident before puberty: AMH levels are normal, in correlation with normal inhibin B and FSH. At puberty, androgens provoke a physiological decrease in serum AMH. However, Sertoli cell function deteriorates progressively from mid-puberty, resulting in extremely low or undetectable $\mathrm{AMH}$, in coincidence with undetectable inhibin $\mathrm{B}$, very high FSH levels and small testis volume [46].

\section{Cryptorchidism}

Cryptorchidism is a clinical sign with many possible aetiologies. It may be one component of the 'testicular dysgenesis syndrome', a primary hypogonadal disorder with 'whole testicular dysfunction' also presenting with hypospadias, as well as reduced semen quality and increased risk of testicular cancer in adults [47]. Alternatively, cryptorchidism may result from anatomical defects of the inguinal region or the abdominal wall (i.e., not associated with hypogonadism), from hypogonadotrophic hypogonadism or from rare mutations of INSL3 or its receptor [3]. According to its aetiology, cryptorchidism may be associated with normal or impaired Sertoli cell function. In boys with bilateral cryptorchidism, AMH is low in approximately $75 \%$ of those with non-palpable gonads and $35 \%$ of those with inguinal gonads, indicating Sertoli cell dysfunction [48]. AMH is expected to be normal, unless longstanding abnormal testis position occurs, in patients with abdominal wall or inguinal region defects or with impaired INSL3 signalling. As already discussed, $\mathrm{AMH}$ is low in patients with cryptorchidism due to congenital hypogonadotrophic hypogonadism [20, 21, 38].

\section{Chemotherapy/Radiotherapy}

Chemotherapy and radiotherapy affect primarily germ cells [49], but Sertoli cells may also be affected as shown by studies reporting low inhibin B/FSH ratios [50]. No studies have reported AMH values.

\section{Primary Hypogonadism with 'Cell-Specific Testicular Dysfunction}

\section{Primary Hypogonadism with Sertoli Cell-Specific Dysfunction}

Inactivating mutations of the FSH receptor provoke Sertoli cell dysfunction resulting in low Sertoli and germ cell numbers leading to reduced testis volume, moder-

AMH and Sertoli Cell Function in

Paediatric Male Hypogonadism ately elevated FSH and low inhibin B [51]. Low AMH could be expected in paediatric patients, but no reports exist in the literature. Since basal AMH secretion in fetal life is independent from FSH, müllerian ducts normally regress in these patients.

Inactivating mutations of the AMH gene, responsible for the $\mathrm{AMH}$-negative form of the persistent müllerian duct syndrome (PMDS), result in extremely low or most often undetectable levels of serum AMH. These cases should be distinguished from the AMH-positive form of PMDS due to AMH receptor mutations, where serum $\mathrm{AMH}$ is normal, indicating that no testicular dysfunction exists [reviewed in 52].

In the androgen insensitivity syndrome (AIS) due to mutations in the androgen receptor gene, attention is usually driven to the lack of virilisation of genitalia. Nevertheless, testicular function is also partially affected. Indeed, Sertoli cells are unable to respond to androgens normally. In the complete form of AIS, FSH does not increase in the first months after birth and $\mathrm{AMH}$ remains in the normal male levels [53]. At pubertal age, if the patient has not yet been gonadectomised, FSH increases leading to very high levels of AMH, which cannot be inhibited by testosterone [26, 27] (fig. 4; table 3). In the partial form of AIS, the early postnatal FSH surge occurs normally driving to higher AMH levels [53]. At pubertal age, the increase in testosterone may partially down-regulate $\mathrm{AMH}$ : serum AMH declines but remains higher than expected for patient's testosterone level [26, 27].

\section{Primary Hypogonadism with Leydig Cell-Specific Dysfunction}

Inactivating mutations of the $\mathrm{LH} / \mathrm{hCG}$ receptor or of the steroidogenic enzymes in 46,XY individuals result in DSD due to isolated hypoandrogenism leading to the development of female or ambiguous external genitalia. At variance with what is observed in whole gonadal dysfunction (i.e., testicular dysgenesis), serum AMH is nor$\mathrm{mal} / \mathrm{high}$, mainly during the first year of life and at pubertal age, owing to the lack of androgen inhibitory effect (fig. 4; table 3) [27].

\section{Primary Hypogonadism with Germ Cell-Specific Dysfunction}

In XX males, $\mathrm{AMH}$ and testosterone are normal, indicating that the somatic cells of the gonads are not primarily affected [27]. However, germ cells fail to progress through gametogenesis and enter apoptosis at puberty. $\mathrm{AMH}$ levels have not been evaluated in other disorders 
where germ cells are the primarily affected population, like DAZ (deleted in azoospermia) microdeletions of the Y chromosome.

Combined Hypogonadism (Central and Primary) with 'Whole Testicular Dysfunction'

DAX1 and SF1 are genes expressed at several levels of the hypothalamic-pituitary-gonadal and adrenal axes [54]. Mutations in the DAX1 gene cause an X-linked disorder presenting with adrenal hypoplasia congenita and combined hypothalamic-pituitary-testicular defects. The latter is characterised by a primary testicular defect, as observed in DAX1 knockout mice [55], and lack of elevation of gonadotrophins, suggestive of an impaired functional capacity of the pituitary. Serum AMH is low, like inhibin B, from early pubertal stages onwards, indicating the existence of a primary failure of testicular function [56].

The phenotypic spectrum associated with SF1 mutations includes different degrees of insufficient virilisation with or without müllerian duct remnant and normal or impaired adrenal function. Endocrine investigations are consistent with gonadal dysgenesis associated with a partial form of hypogonadotrophic hypogonadism [57]. $\mathrm{AMH}$ and testosterone are very low, probably due to a multifactorial pathophysiology including gonadal dysgenesis, lack of SF1 as a transcription factor for $\mathrm{AMH}$ gene expression and insufficient gonadotrophin secretion.
In prepubertal male patients with Prader-Willi syndrome, a specific form of combined central and peripheral hypogonadism, AMH is normal/low, inhibin B is low, FSH is normal/high, and $\mathrm{LH}$ and testosterone are normal/low [58-60]. Sertoli cell function has not been assessed either in children exposed to total body irradiation during cancer treatment.

\section{Concluding Remarks}

Hypogonadism can be overlooked in infancy and childhood if attention is driven only to gonadotrophins and testosterone. Sertoli cells are the main active population between birth and pubertal onset. Small testes in this period reflect Sertoli cell defects, either primary or secondary to FSH deficiency. Sertoli cell markers, like serum $\mathrm{AMH}$ and inhibin $\mathrm{B}$, are most helpful in the evaluation of gonadal function, without any need for stimulation tests, and orientate the aetiological diagnosis of male hypogonadism in paediatric patients. Serum AMH is an excellent marker of FSH and androgen action in the testis.

\section{Acknowledgement}

Rodolfo A. Rey has received royalties from Beckman-Coulter France as inventor of AMH/MIS ELISA ${ }^{\circledR}$.

\section{References}

1 Petersen C, Söder O: The Sertoli cell: a hormonal target and 'super' nurse for germ cells that determines testicular size. Horm Res 2006;66:153-161.

2 Svechnikov K, Söder O: Ontogeny of gonadal sex steroids. Best Pract Res Clin Endocrinol Metab 2008;22:95-106.

3 Ivell R, Hartung S: The molecular basis of cryptorchidism. Mol Hum Reprod 2003;9: 175-181.

4 Bergadá I, Milani C, Bedecarrás $\mathrm{P}$, Andreone L, Ropelato MG, Gottlieb S, Bergadá C, Campo S, Rey RA: Time course of the serum gonadotropin surge, inhibins, and anti-müllerian hormone in normal newborn males during the first month of life. J Clin Endocrinol Metab 2006;91:4092-4098.
5 Forest MG, Sizonenko PC, Cathiard AM, Bertrand J: Hypophyso-gonadal function in humans during the first year of life. 1. Evidence for testicular activity in early infancy. J Clin Invest 1974;53:819-828.

6 Müller J, Skakkebæk NE: Quantification of germ cells and seminiferous tubules by stereological examination of testicles from 50 boys who suffered from sudden death. Int J Androl 1983;6:143-156.

7 Nistal M, Abaurrea MA, Paniagua R: Morphological and histometric study on the human Sertoli cell from birth to the onset of puberty. J Anat 1982;134:351-363.

8 Pasqualini T, Chemes H, Rivarola MA: Testicular testosterone levels during puberty in cryptorchidism. Clin Endocrinol 1981;15: 545-554.
9 Rey R, Lukas-Croisier C, Lasala C, Bedecarrás $\mathrm{P}: \mathrm{AMH} / \mathrm{MIS}$ : what we know already about the gene, the protein and its regulation. Mol Cell Endocrinol 2003;211:21-31.

10 Bergadá I, Rojas G, Ropelato MG, Ayuso S, Bergadá C, Campo S: Sexual dimorphism in circulating monomeric and dimeric inhibins in normal boys and girls from birth to puberty. Clin Endocrinol 1999;51:455-460.

-11 Josso N, Lamarre I, Picard JY, Berta P, Davies N, Morichon N, Peschanski M, Jeny R: Antimüllerian hormone in early human development. Early Hum Dev 1993;33:91-99.

12 Guibourdenche J, Lucidarme N, Chevenne D, Rigal O, Nicolas $M$, Luton D, Leger J, Porquet D, Noel M: Anti-müllerian hormone levels in serum from human foetuses and children: pattern and clinical interest. Mol Cell Endocrinol 2003;211:55-63. 
13 Long WQ, Ranchin V, Pautier P, Belville C, Denizot P, Cailla H, Lhommé C, Picard JY, Bidart JM, Rey R: Detection of minimal levels of serum anti-müllerian hormone during follow-up of patients with ovarian granulosa cell tumor by means of a highly sensitive enzyme-linked immunosorbent assay. J Clin Endocrinol Metab 2000;85:540-544.

14 De Santa Barbara P, Bonneaud N, Boizet B, Desclozeaux M, Moniot B, Sudbeck P, Scherer G, Poulat F, Berta P: Direct interaction of SRY-related protein SOX9 and steroidogenic factor 1 regulates transcription of the human anti-müllerian hormone gene. Mol Cell Biol 1998;18:6653-6665.

$\checkmark 15$ Arango NA, Lovell-Badge R, Behringer RR: Targeted mutagenesis of the endogenous mouse Mis gene promoter: in vivo definition of genetic pathways of vertebrate sexual development. Cell 1999;99:409-419.

16 Shen WH, Moore CC, Ikeda Y, Parker KL, Ingraham HA: Nuclear receptor steroidogenic factor 1 regulates the müllerian inhibiting substance gene: a link to the sex determination cascade. Cell 1994;77:651-661.

17 Watanabe K, Clarke TR, Lane AH, Wang X, Donahoe PK: Endogenous expression of müllerian inhibiting substance in early postnatal rat Sertoli cells requires multiple steroidogenic factor-1 and GATA-4-binding sites. Proc Natl Acad Sci USA 2000;97:16241629.

-18 Viger RS, Mertineit C, Trasler JM, Nemer M: Transcription factor GATA- 4 is expressed in a sexually dimorphic pattern during mouse gonadal development and is a potent activator of the müllerian inhibiting substance promoter. Development 1998;125:26652675.

19 Hossain A, Saunders GF: Role of Wilms tumor 1 (WT1) in the transcriptional regulation of the müllerian-inhibiting substance promoter. Biol Reprod 2003;69:1808-1814.

20 Bougnères P, François M, Pantalone L, Rodrigue D, Bouvattier C, Demesteere E, Roger D, Lahlou N: Effects of an early postnatal treatment of hypogonadotropic hypogonadism with a continuous subcutaneous infusion of recombinant follicle-stimulating hormone and luteinizing hormone. J Clin Endocrinol Metab 2008;93:2202-2205.

21 Young J, Chanson P, Salenave S, Noël M, Brailly S, O'Flaherty M, Schaison G, Rey R: Testicular anti-müllerian hormone secretion is stimulated by recombinant human FSH in patients with congenital hypogonadotropic hypogonadism. J Clin Endocrinol Metab 2005;90:724-728.
22 Lukas-Croisier C, Lasala C, Nicaud J, Bedecarrás P, Kumar TR, Dutertre M, Matzuk MM, Picard JY, Josso N, Rey R: Follicle-stimulating hormone increases testicular antimüllerian hormone production through Sertoli cell proliferation and a nonclassical cyclic adenosine 5'-monophosphate-mediated activation of the AMH gene. Mol Endocrinol 2003;17:550-561.

23 Al-Attar L, Noël K, Dutertre M, Belville C, Forest MG, Burgoyne PS, Josso N, Rey R: Hormonal and cellular regulation of Sertoli cell anti-müllerian hormone production in the postnatal mouse. J Clin Invest 1997;100: 1335-1343.

24 Rey R, Lordereau-Richard I, Carel JC, Barbet $\mathrm{P}$, Cate RL, Roger M, Chaussain JL, Josso N: Anti-müllerian hormone and testosterone serum levels are inversely related during normal and precocious pubertal development. J Clin Endocrinol Metab 1993;77: $1220-1226$.

25 Josso N, Legeai L, Forest MG, Chaussain JL, Brauner R: An enzyme-linked immunoassay for anti-müllerian hormone: a new tool for the evaluation of testicular function in infants and children. J Clin Endocrinol Metab 1990;70:23-27.

26 Rey R, Mebarki F, Forest MG, Mowszowicz I, Cate RL, Morel Y, Chaussain JL, Josso N: Anti-müllerian hormone in children with androgen insensitivity. J Clin Endocrinol Metab 1994;79:960-964.

27 Rey RA, Belville C, Nihoul-Fékété C, Michel-Calemard L, Forest MG, Lahlou N, Jaubert F, Mowszowicz I, David M, Saka N, Bouvattier C, Bertrand AM, Lecointre C, Soskin S, Cabrol S, Crosnier H, Léger J, Lortat-Jacob S, Nicolino M, Rabl W, Toledo SP, Bas F, Gompel A, Czernichow P, Josso N: Evaluation of gonadal function in 107 intersex patients by means of serum anti-müllerian hormone measurement. J Clin Endocrinol Metab 1999;84:627-631.

28 Chemes HE, Rey RA, Nistal M, Regadera J, Musse M, Gonzalez-Peramato P, Serrano A: Physiologic androgen insensitivity of the fetal, neonatal, and early infantile testis is explained by the ontogeny of the androgen receptor expression in Sertoli cells. J Clin Endocrinol Metab 2008;93:4408-4412.

29 Berensztein EB, Baquedano MS, Gonzalez CR, Saraco NI, Rodriguez J, Ponzio R, Rivarola MA, Belgorosky A: Expression of aromatase, estrogen receptor $\alpha$ and $\beta$, androgen receptor, and cytochrome P450scc in the human early prepubertal testis. Pediatr Res 2006;60:740-744.

30 Boukari K, Meduri G, Brailly-Tabard S, Guibourdenche J, Ciampi ML, Massin N, Martinerie L, Picard JY, Rey R, Lombès M, Young $\mathrm{J}$ : Lack of androgen receptor expression in Sertoli cells accounts for the absence of antimüllerian hormone repression during early human testis development. J Clin Endocrinol Metab 2009;94:1818-1825.
31 Rey R, Al-Attar L, Louis F, Jaubert F, Barbet $\mathrm{P}$, Nihoul-Fékété C, Chaussain JL, Josso N: Testicular dysgenesis does not affect expression of anti-müllerian hormone by Sertoli cells in premeiotic seminiferous tubules. Am J Pathol 1996;148:1689-1698.

32 Andersson AM: Inhibin B in the assessment of seminiferous tubular function. Baillieres Best Pract Res Clin Endocrinol Metab 2000; 14:389-397.

33 Rey R: Assessment of seminiferous tubule function (anti-müllerian hormone). Baillieres Best Pract Res Clin Endocrinol Metab 2000;14:399-408.

34 Bergadá I, Bergadá C, Campo S: Role of inhibins in childhood and puberty. J Pediatr Endocrinol Metab 2001;14:343-353.

35 Lee MM, Misra M, Donahoe PK, MacLaughlin DT: MIS/AMH in the assessment of cryptorchidism and intersex conditions. Mol Cell Endocrinol 2003;211:91-98.

36 Lee MM, Donahoe PK, Silverman BL, Hasegawa T, Hasegawa Y, Gustafson ML, Chang YC, MacLaughlin DT: Measurements of serum müllerian inhibiting substance in the evaluation of children with nonpalpable gonads. N Engl J Med 1997;336:1480-1486.

37 Josso N: Paediatric applications of anti-müllerian hormone research. 1992 Andrea Prader Lecture. Horm Res 1995;43:243-248.

38 Young J, Rey R, Couzinet B, Chanson P, Josso N, Schaison G: Anti-müllerian hormone in patients with hypogonadotropic hypogonadism. J Clin Endocrinol Metab 1999;84: 2696-2699.

-39 Berensztein E, Saraco N, Belgorosky A, Rivarola MA: Secretion of inhibin B by human prepubertal testicular cells in culture. Eur J Endocrinol 2000;142:481-485.

40 Berensztein EB, Baquedano MS, Pepe CM, Costanzo M, Saraco NI, Ponzio R, Rivarola MA, Belgorosky A: Role of IGFs and insulin in the human testis during postnatal activation: differentiation of steroidogenic cells. Pediatr Res 2008;63:662-666.

41 Layman LC, Lee EJ, Peak DB, Namnoum AB, $\mathrm{Vu} \mathrm{KV}$, van Lingen $\mathrm{BL}$, Gray $\mathrm{MR}$, McDonough PG, Reindollar RH, Jameson JL: Delayed puberty and hypogonadism caused by mutations in the follicle-stimulating hormone $\beta$-subunit gene. N Engl J Med 1997; 337:607-611.

42 Weiss J, Axelrod L, Whitcomb RW, Harris PE, Crowley WF, Jameson JL: Hypogonadism caused by a single amino acid substitution in the beta subunit of luteinizing hormone. N Engl J Med 1992;326:179-183.

43 MaX, Dong Y, Matzuk MM, Kumar TR: Targeted disruption of luteinizing hormone $\beta$ subunit leads to hypogonadism, defects in gonadal steroidogenesis, and infertility. Proc Natl Acad Sci USA 2004;101:17294-17299. 
-44 Misra M, MacLaughlin DT, Donahoe PK, Lee MM: The role of müllerian inhibiting substance in the evaluation of phenotypic female patients with mild degrees of virilization. J Clin Endocrinol Metab 2003;88:787792.

45 Rey RA, Codner E, Iñíguez G, Bedecarrás P, Trigo R, Okuma C, Gottlieb S, Bergadá I, Campo SM, Cassorla FG: Low risk of impaired testicular Sertoli and Leydig cell functions in boys with isolated hypospadias. J Clin Endocrinol Metab 2005;90:60356040.

46 Bastida MG, Rey RA, Bergadá I, Bedecarrás P, Andreone L, del Rey G, Boywitt A, Ropelato MG, Cassinelli H, Arcari A, Campo S, Gottlieb S: Establishment of testicular endocrine function impairment during childhood and puberty in boys with Klinefelter syndrome. Clin Endocrinol 2007;67:863870.

-47 Skakkebæk NE, Rajpert-De Meyts E, Main KM: Testicular dysgenesis syndrome: an increasingly common developmental disorder with environmental aspects: opinion. Hum Reprod 2001;16:972-978.

48 Misra M, MacLaughlin DT, Donahoe PK, Lee MM: Measurement of müllerian inhibiting substance facilitates management of boys with microphallus and cryptorchidism. J Clin Endocrinol Metab 2002;87:3598-3602.

49 Shalet SM, Tsatsoulis A, Whitehead E, Read G: Vulnerability of the human Leydig cell to radiation damage is dependent upon age. J Endocrinol 1989;120:161-165.
50 Bordallo MA, Guimaraes MM, Pessoa $\mathrm{CH}$, Carrico MK, Dimetz T, Gazolla HM, Dobbin J, Castilho IA: Decreased serum inhibin B/ FSH ratio as a marker of Sertoli cell function in male survivors after chemotherapy in childhood and adolescence. J Pediatr Endocrinol Metab 2004;17:879-887.

51 Tapanainen JS, Aittomaki K, Min J, Vaskivuo T, Huhtaniemi IT: Men homozygous for an inactivating mutation of the follicle-stimulating hormone receptor gene present variable suppression of spermatogenesis and fertility. Nat Genet 1997;15:205-206.

52 Josso N, Belville C, di Clemente N, Picard JY: $\mathrm{AMH}$ and $\mathrm{AMH}$ receptor defects in persistent müllerian duct syndrome. Hum Reprod Update 2005;11:351-356.

53 Bouvattier C, Carel JC, Lecointre C, David A, Sultan C, Bertrand AM, Morel Y, Chaussain JL: Postnatal changes of T, LH, and FSH in $46, \mathrm{XY}$ infants with mutations in the $\mathrm{AR}$ gene. J Clin Endocrinol Metab 2002;87:2932.

$54 \mathrm{Yu}$ RN, Achermann JC, Ito M, Jameson JL: The role of DAX-1 in reproduction. Trends Endocrinol Metab 1998;9:169-175.

55 Meeks JJ, Crawford SE, Russell TA, Morohashi K, Weiss J, Jameson JL: Dax1 regulates testis cord organization during gonadal differentiation. Development 2003;130:10291036.
56 Bergadá I, Andreone L, Bedecarrás P, Ropelato MG, Copelli S, Laissue P, Rey RA, Campo S: Seminiferous tubule function in delayed-onset $\mathrm{X}$-linked adrenal hypoplasia congenita associated with incomplete hypogonadotrophic hypogonadism. Clin Endocrinol (Oxf) 2008;68:240-246.

57 Lin L, Philibert P, Ferraz-de-Souza B, Kelberman D, Homfray T, Albanese A, Molini V, Sebire NJ, Einaudi S, Conway GS, Hughes IA, Jameson JL, Sultan C, Dattani MT, Achermann JC: Heterozygous missense mutations in steroidogenic factor 1 (SF1/Ad4BP, NR5A1) are associated with 46,XY disorders of sex development with normal adrenal function. J Clin Endocrinol Metab 2007;92: 991-999.

58 Eiholzer U, l'Allemand D, Rousson V, Schlumpf M, Gasser T, Girard J, Gruters A, Simoni M: Hypothalamic and gonadal components of hypogonadism in boys with Prader-Labhart-Willi syndrome. J Clin Endocrinol Metab 2006;91:892-898.

59 Fillion M, Deal CL, Van Vliet G: Normal minipuberty of infancy in boys with PraderWilli syndrome. J Pediatr 2006; 149:874876.

60 Hirsch HJ, Eldar-Geva T, Benarroch F, Rubinstein $\mathrm{O}$, Gross-Tsur V: Primary testicular dysfunction is a major contributor to abnormal pubertal development in males with Prader-Willi syndrome. J Clin Endocrinol Metab 2009;94:2262-2268. 